\title{
EVALUATION OF THE ANALGESIC ACTIVITY OF AQUEOUS AND ALCOHOLIC EXTRACT OF FLOWERS OF PLUMERIA ALBA LINN IN EXPERIMENTAL ANIMALS
}

\author{
SATHIYA VINOTHA AT ${ }^{1 *}$, UMAMAGESWARI MS ${ }^{1}$, UMAMAHESWARI ${ }^{2}$, VELARUL $\mathbf{S}^{1}$
}

${ }^{1}$ Department of Pharmacology, KMCH Institute of Health Sciences and Research, Coimbatore, Tamil Nadu, India. ${ }^{2}$ Department of Pharmacology, PSG Institute of Medical Sciences and Research, Coimbatore. Email: drs.vinotha19@gmail.com

Received: 28 December 2020, Revised and Accepted: 11 February 2021

\section{ABSTRACT}

Objective: Plumeria alba (Apocynaceae), commonly known as "Frangipani" is an important medicinal plant, widely distributed throughout Southern India. In the traditional medicinal system, different parts of this plant have been mentioned to be useful in a wide variety of diseases. In this study, analgesic activity of aqueous and alcoholic extract of flowers of $P$. alba Linn was evaluated by hot-plate and acetic acid-induced writhing methods to substantiate and expand its clinical applications.

Methods: The flowers of P. alba were collected from the local area in and around Coimbatore (India). The flowers were dried, powdered, and were extracted using soxhlet apparatus for $12 \mathrm{~h}$ using water and $95 \%$ of ethanol as a solvent. The test extracts were administered orally at a dose of 100 \& $200 \mathrm{mg} / \mathrm{kg}$ while diclofenac sodium $(10 \mathrm{mg} / \mathrm{kg})$ served as standard.

Results: The ethanolic flower extract of $200 \mathrm{mg} / \mathrm{kg}$ had significant analgesic activity in acetic acid-induced abdominal writhing response (*** $\mathrm{p}<0.001$ ) when compared to control and standard drug diclofenac. It also exhibited significant analgesic activity $\left({ }^{* * *} \mathrm{p}<0.001\right)$ by increasing the pain reaction time of the rats in comparison to control and standard in hot plate method.

Conclusion: The results suggest that ethanolic flower extracts of $P$. alba possess potent analgesic properties, which support its use in traditional medicine and suggesting that the plant should be further investigated for its pharmacological active natural products.

Keywords: Analgesic activity, Acetic acid-induced writhing method, Hot-plate, Plumeria alba.

(C) 2021 The Authors. Published by Innovare Academic Sciences Pvt Ltd. This is an open access article under the CC BY license (http://creativecommons.org/ licenses/by/4.0/) DOI: http://dx.doi.org/10.22159/ajpcr.2021v14i4.40644. Journal homepage: https://innovareacademics.in/journals/index.php/ajpcr

\section{INTRODUCTION}

Pain is an unpleasant sensation and emotional experience associated with real or potential tissue damage or described in terms of such damage. The pathophysiology of pain involves two components, peripheral nociception, and central mechanism. Analgesics are the drugs that selectively relieve pain by acting in the central nervous system (CNS) or on the peripheral pain mechanisms, without appreciably altering consciousness. With the easy availability of analgesics (opioids) and anti-inflammatory drugs (nonsteroidal anti-inflammatory drugs [NSAIDs]), we are facing a new era of people presenting with symptoms of analgesic abuse [1,2]. With the development of more and more synthetic drugs that have their unique adverse effects, it is high time that attention should be turned to the possible remedies that may be found among indigenous herbal plants. This has accelerated the global effort to harvest those medicinal plants that have substantial beneficial effects with the least adverse effects to remove pain stimulus. The medicinal plants have been used in traditional medicine for hundreds of years with a reputation as efficacious remedies although there may not sufficient scientific data to substantiate their efficacy. Large numbers of these plants are important in the modern pharmaceutical industry. They serve as therapeutic agents and raw materials for the manufacturer of traditional and modern medicines. These plants are rich sources of bioactive compounds and thus serve as important raw materials for drug production. It has now been established that the plants synthesize and accumulate some secondary metabolites such as alkaloids, glycosides, tannins, and volatile oils that may possess a great potential for biological activity and can be a curative agent in therapeutic purposes [3]. The therapeutic use of plants continued with the progress of civilization and the development of human knowledge.

Plumeria alba Linn (Apocynaceae) commonly called White Champa, a small laticiferous tree or shrub, a native of tropical America. It is $4.5 \mathrm{~m}$ high, occasionally growing in the gardens. The plant is mainly grown for its ornamental and fragrant flowers. Leaves are lanceolate. The flower of the plant is white with yellow centers. Fragrant in corymbose fascicles Frangipani is well known for its intense fragrance and spiralshaped blooms narrowly strap-like leaves stay on the tree for most of the year. The white flowers with a yellow center have an almost waxy feel. After flowering narrowly cylindrical pods borne in pairs attached at the base and filled with winged seeds are sometimes produced $[4,5]$.

Studies have shown that opiates cause physical dependency, tolerance, and addiction while NSAIDs usually cause gastrointestinal disorders. As such, research to discover other alternatives to treat pain is crucial. Many of these herbs with analgesic activity had been used without any adverse effects. The present study aimed to evaluate the analgesic activity of ethanol and aqueous flower extracts of $P$. alba in animal models.

\section{METHODS}

Wistar albino rats of either sex weighing between 150 and $200 \mathrm{~g}$ were randomly selected from the central animal facility. The animals were fed with Purina Chow diet, water ad libitum, and maintained under standard conditions of temperature, humidity, and light $(12 \mathrm{~h}$ light/12 $\mathrm{h}$ dark cycle). All the animals were maintained in accordance with the guidelines of CPCSEA. All the experiments were conducted after approval by the Institutional Animal Ethical Committee. Pregnant animals, animals with injuries, disease, infection, and deformity were excluded from the study.

\section{Preparation of the extract}

Fresh flowers of $P$. alba were collected from the rural areas of Coimbatore. P. alba L. (White champa) was identified and authenticated 
from agricultural university Coimbatore. The flowers were dried under shade and made to a fine powder and were extracted with water and alcohol by using a Soxhlet apparatus.

\section{Chemicals}

A soluble form of diclofenac $(10 \mathrm{mg} / \mathrm{kg}$ ) was used as a standard drug and $0.7 \% \mathrm{v} / \mathrm{v}$ acetic acid was used to induce writhing in mice. All the chemicals were obtained from ACME Laboratories Ltd.

\section{Experimental design}

Analgesic activity of $P$. alba was assessed with two experimental models, namely, acetic acid-induced writhing test and Eddy's hot plate method. Rats were divided into six groups ( $\mathrm{n}=6$ /group). The grouping for pharmacological screening models was as follows:

Group I (control): Rats received $0.5 \mathrm{ml}$ normal saline.

Group II (standard): Rats received diclofenac $(1.0 \mathrm{mg} / \mathrm{kg})[6]$.

Group III: Rats were treated with aqueous flower extracts of $P$. alba (AFEPA) $100 \mathrm{mg} / \mathrm{kg}$.

Group IV: Rats were treated with aqueous flower extracts of $P$. alba (AFEPA) $200 \mathrm{mg} / \mathrm{kg}$.

Group V: Rats were treated with alcoholic flower extract of P. alba (EFEPA) $100 \mathrm{mg} / \mathrm{kg}$.

Group VI: Rats were treated with alcoholic flower extract of $P$. alba (EFEPA) $200 \mathrm{mg} / \mathrm{kg}$ [7].

\section{Acetic acid-induced writhing test}

Rats were orally administered with test and control drugs $30 \mathrm{~min}$ before intraperitoneal injection of acetic acid $(0.6 \%)$. Then rats were placed in separate bell-shaped transparent glass jars and numbers of abdominal constrictions (writhes) were counted for a period of $10 \mathrm{~min}$ commencing $10 \mathrm{~min}$ after injection of acetic acid. The difference in a number of writhes in the test group was compared with standard and control, treated groups. The percentage increase/decrease in number of writhing (as an index of analgesia) was calculated. The percentage inhibition was calculated by the formula:

\section{$\%$ Inhibition $=[(\mathrm{Wc}-\mathrm{Wt}) \times 100] / \mathrm{Wc}$}

Where, Wc=No. of writhes in the control group, $\mathrm{Wt}=$ No of writhes in the test group [8].

\section{Eddy's hot plate method}

Rats were orally administered with test and control drugs. $1 \mathrm{~h}$ after the ingestion of drugs rats were placed on the hot plate, which consists of an electrically heated surface. The temperature of the hot plate was maintained at $55^{\circ} \mathrm{C}$. Responses such as jumping, withdrawal of the paws, and licking of the paws were observed. The time period, when animals were placed and until responses occur was noted as latency period by the stopwatch. The latency period was recorded after 0,60 , 90 , and 120 min. These values were compared with the standard drug diclofenac and control normal saline. This model evaluates the central pain [9].

\section{Statistical analysis}

Data obtained from the experiment was expressed as Mean \pm SEM. Differences between the control and the treatments in these experiments were tested for significance using one-way analysis of variance.

\section{RESULTS}

\section{Acetic acid-induced writhing response}

The effect of ethanolic and aqueous flower extracts of $P$. alba on the acetic acid- induced abdominal constrictions in the rat is presented in Table 1. The result shows that ethanolic and aqueous extracts $(200 \mathrm{mg} / \mathrm{kg})$, and the standard drug diclofenac sodium $(25 \mathrm{mg} / \mathrm{kg})$ more significantly $(p<0.001)$ reduced abdominal writhing in rats when compared to the control group The number of writhing was reduced from $40.2 \pm 1.2$ in the control group to $19.3 \pm 1.8$ at a dose of $200 \mathrm{mg} / \mathrm{kg}$ of ethanolic extract of $P$. alba. The reduction was in a dose-dependent
Table 1: Percentage inhibition among groups in acetic acid-induced writhing in rat

\begin{tabular}{llll}
\hline Groups & Drug & $\begin{array}{l}\text { No. of } \\
\text { writhes }\end{array}$ & $\begin{array}{l}\text { Percentage } \\
\text { inhibition }\end{array}$ \\
\hline $\begin{array}{l}\text { Group I } \\
\text { (Control) }\end{array}$ & Normal saline $0.5 \mathrm{ml}$ & $40.2 \pm 1.2$ & - \\
$\begin{array}{l}\text { Group II } \\
\text { (Standard) }\end{array}$ & Diclofenac $25 \mathrm{mg} / \mathrm{kg}$ & $17.5 \pm 1.5^{* * *}$ & 57.5 \\
Group III & AFEPA $100 \mathrm{mg} / \mathrm{kg}$ & $29.3 \pm 0.2$ & 27.5 \\
Group IV & AFEPA $200 \mathrm{mg} / \mathrm{kg}$ & $28.2 \pm 2.2$ & 30 \\
Group V & EFEPA100 mg/kg & $21.3 \pm 1.4$ & 47.5 \\
Group VI & EFEPA $200 \mathrm{mg} / \mathrm{kg}$ & $19.3 \pm 1.8^{* * *}$ & 51.9 \\
\hline
\end{tabular}

Values are expressed as Mean \pm SEM $(\mathrm{n}=6){ }^{* * *} \mathrm{p}<0.001$ as compared to Group I (control)

manner. Furthermore, the extract caused a dose-dependent increase in inhibition of abdominal writhing, increasing it from $0 \%$ in the control group to $51.9 \%$ at the dose $200 \mathrm{mg} / \mathrm{kg}$ of ethanolic extract. Both the extracts at a dose of $100 \mathrm{mg} / \mathrm{kg}$ are also significant $(\mathrm{p}<0.05)$ when compared to the control group. $200 \mathrm{mg} / \mathrm{kg}$ of ethanolic extracts was found more potent than all other extracts.

\section{Hot plate method}

The result of the effect of ethanolic and aqueous flower extracts of P. alba on the hot plate method is presented in Table 2. The standard drug diclofenac sodium showed a significant increase in analgesic activity when compared with the control $(\mathrm{p}<0.001)$. The result shows that the latency period of ethanolic flower extract $200 \mathrm{mg} / \mathrm{kg}$ was significantly good when compared to control $(\mathrm{p}<0.001)$. The aqueous flower extracts showed significance when compared to Group II $(\mathrm{p}<0.05) .100 \mathrm{mg} / \mathrm{kg}$ and $200 \mathrm{mg} / \mathrm{kg}$ of ethanolic extracts show significance in mean reaction time when compared to Group II $(\mathrm{p}<0.001)$.

\section{DISCUSSION}

The present study was designed to evaluate the analgesic potential of aqueous and ethanolic extracts of flowers of $P$. alba and to explore the mechanism in Wistar albino rats. The three major classes of pain initiation are (a) acute high - intensity stimuli; (b) tissue injury and inflammation; and (c) injury to a specific peripheral nerve (mononeuropathy, e.g. crush, section) or to all peripheral sensory nerves (polyneuropathy, e.g. diabetes, chemotherapy, or an immunemediated reaction). Excitation of nociceptors or their afferent free nerve endings leads to pain. Pain is mediated through A $\delta$ fibers and C fibers, respectively, called fast and slow pain. Nociception is the mechanism; whereby noxious peripheral stimuli are transmitted to the central nervous system. Nociceptive fibers terminate in the superficial layers of the dorsal horn, forming synaptic connections with transmission neurons running to the thalamus. Neurogenic inflammation occurs due to the release of transmitters glutamate, substance P from the nociceptors [10]. NSAIDs and opioid drugs are the commonly prescribed analgesic drugs for inflammatory and chronic pain, respectively. These drugs relieve pain peripherally/ centrally by inhibiting cyclooxygenase enzyme (COX-1 and COX-2). Pain mediators such as prostaglandins, substance $\mathrm{P}$, histamine, serotonin, and bradykinin are reduced due to the inhibition of the cyclooxygenase enzyme [11]. The peripherally acting analgesics are commonly assessed by acetic acid-induced writhing test, which involves mainly acetylcholine and histamine mediators. Phenyl quinone and acetic acid are commonly used chemicals to induce writhing in animals. Due to the involvement of peritoneal receptors, contraction of the abdominal muscle, elongation of the body part, and extension of the hind limbs occur when acetic acid is injected intraperitoneally [12]. It has been proposed that acetic acid produces pain indirectly by releasing endogenous substances responsible for exciting the nerve endings. Eddy's hot plate method involves higher brain functions and pain is produced by the supraspinal mediated response. In this study, both aqueous and ethanolic extracts of $P$. alba 
Table 2: Reaction time in seconds among groups in Eddy's hot plate method

\begin{tabular}{|c|c|c|c|c|c|}
\hline \multirow[t]{2}{*}{ Groups } & \multirow[t]{2}{*}{ Drug } & \multicolumn{4}{|c|}{ Reaction time in seconds } \\
\hline & & $0 \mathrm{~min}$ & $60 \mathrm{~min}$ & $90 \mathrm{~min}$ & $120 \mathrm{~min}$ \\
\hline Group I (Control) & Normal saline & $23.2 \pm 3.2$ & $23.82 \pm 1.6$ & $25.3 \pm 1.4$ & $25.8 \pm 0.8$ \\
\hline Group III & AFEPA 100 mg/kg & $38.8 \pm 2.9$ & $40.9 \pm 3.6$ & $43.8 \pm 4.3$ & $48.6 \pm 3.9$ \\
\hline Group IV & AFEPA $200 \mathrm{mg} / \mathrm{kg}$ & $39.4 \pm 1.9$ & $41.2 \pm 3.2$ & $43.9 \pm 2.3$ & $49.8 \pm 3.8$ \\
\hline Group V & EFEPA 100 mg/kg & $50.2 \pm 3.4$ & $52.8 \pm 2.9$ & $55.8 \pm 3.4$ & $56.4 \pm 2.7$ \\
\hline Group VI & EFEPA $200 \mathrm{mg} / \mathrm{kg}$ & $56.2 \pm 3.4$ & $58.3 \pm 1.8$ & $58.6 \pm 2.8$ & $59.8 \pm 3.5^{* * *}$ \\
\hline
\end{tabular}

Values are expressed as Mean \pm SEM $(\mathrm{n}=6) .{ }^{* * *} \mathrm{p}<0.001$ as compared to Group I (control)

reduces the number of writhes and increases the reaction time in acetic acid-induced writhing test and hot plate test, respectively [13]. These findings strongly suggest that aqueous and ethanolic flower extracts of $P$. alba possess peripheral and central analgesic properties [14]. These results concur with other research studies on $P$. alba using laboratory animals. The flower of $P$. alba has been reported to have antibacterial activities against Escherichia coli, Proteus vulgaris, and many other microbes. It also possesses antioxidant activity which might be due to its Vitamin C content $[15,16]$. Some species of this plant also possess nephroprotective action against cytotoxic drug-induced nephrotoxicity [17]. The cytotoxicity study of $P$. alba flowers proposed that it has potential as an anticancer, especially for colorectal cancer. An earlier study on ethanolic extracts of $P$. alba showed an anti-inflammatory effect in arthritis which may be due to inhibition of phospholipase A2 and prostaglandins [18]. Perhaps acting similarly as conventionally used therapeutic drugs that reduce the pain perception in nociceptors by inhibiting the production of prostaglandins. Many research studies on herbal plants have linked the presence of secondary active metabolites such as flavonoids, saponins, and alkaloids to analgesic activities among other properties [19]. Preliminary phytochemical screening revealed the presence of steroids, flavonoid, and alkaloids in extracts of the flower of $P$. alba. Flavonoids can disrupt the synthesis of eicosanoids. Flavonoids also can reduce the production of arachidonic acid through inhibition of neutrophils degranulation. Besides flavonoids, alkaloids also have been associated with the ability to inhibit pain perception. The plant may have the phytoconstituents which inhibit cyclooxygenase enzyme or act on central opioid receptors and receptors [20].

\section{CONCLUSION}

The results suggest that ethanolic flower extracts of $P$. alba possess potent analgesic properties, which support its use in traditional medicine and suggesting that the plant should be further investigated for its pharmacological active natural products. The findings can be further studied using other experimental methods such as tail flick method which was not used in our study and can be extended to human studies.

\section{AUTHORS' CONTRIBUTIONS}

All the authors contributed equally in experimental work and manuscript preparation.

\section{CONFLICTS OF INTEREST}

The authors declared no conflicts of interest regarding the research, authorship, and publication of this article.

\section{AUTHORS' FUNDING}

Self.

\section{REFERENCES}

1. Sherrington S. The Integrative Action of Nervous System. United Kingdom: Yale University Press; 1920.

2. International Association for the Study of Pain, IASP Taxonomy; 2015. Available from: https://www.iasp-pain.org/education/content.aspx. itemnumber $=1698$. [Last accessed on 2015 Jan 23].

3. Sang CN. NMDA receptor antagonists in neuropathic pain: Experimental methods to clinical trials. J Pain Symptom Manage 2000;19 Suppl 1:21-5.

4. Shinde PR, Patil PS, Bairagi V. A phytopharmacological review of Plumeria species. Sch Acad J Pharm 2014;3:217-27.

5. Devprakash D, Tembare R, Gurav S, Kumar GP, Tamizhmani T. A review of phytochemical constituents and pharmacological activity of Plumeria species. Int J Curr Pharm Res 2012;4:1-6.

6. Gaur K, Rana C, Nema RK, Kori ML, Sharma CS. Anti-inflammatory and analgesic activity of hydro-alcoholic leaves extract of Euphorbia neriifolia Linn. Asian J Pharm Clin Res 2009;2:26-9.

7. Tessou KZ, Lawson-Evi P, Metowogo K, Diallo A, Eklu-Gadegkeku K, Aklikokou K, et al. Acute and sub-acute toxicity studies of Plumeria alba Linn. (Apocynaceae) hydroalcoholic extract in rat. Int J Biomed Sci 2013;9:255-9.

8. Gawade SP. Acetic acid induced painful endogenous infliction in writhing test on mice. J Pharmacol Pharmacother 2012;3:348.

9. Fan SH, Ali NA, Basri DF. Evaluation of analgesic activity of the methanol extract from the galls of Quercus infectoria (Olivier) in Rats. Evid Based Complement Alternat Med 2014;2014:976764.

10. Rajagopal MR. Pain-basic consideration. Indian J Anaesth 2006;50:332-4.

11. Le Bars D, Adam F. Nociceptors and mediators in acute inflammatory pain. Ann Fr Anesth Reanim 2002;21:315-35.

12. Zaheer Z, Konale AG, Patel KA, Khan S, Ahmed RZ. Comparative phytochemical screening of flowers of Plumeria alba and Plumeria rubra. Asian J Pharm Clin Res 2010;3:88-9.

13. Barua CC, Roy JD, Buragohain B, Barua AG, Borah P, Lahkar M. Analgesic and anti-nociceptive activity of hydroethanolic extract of Drymaria cordata Willd. Indian J Pharmacol 2011;43:121-5.

14. Anggoro B, Istyastono E, Hariono M. Future molecular medicine from white frangipani (Plumeria alba L.): A review. J Med Plants Res 2020;14:544-54.

15. Choudhary M, Kumar V, Gupta P, Singh S. Investigation of antiarthritic potential of Plumeria alba L. leaves in acute and chronic models of arthritis. Biomed Res Int 2014;2014:474616.

16. Engineer AS, Pal S, Desai KR, Highland HN. Synergistic antioxidant action of Murraya koenigii and Plumeria rubra extracts enhance hepatoprotective efficacy against methotrexate induced liver injury. Int J Pharm Pharm Sci 2017;9:152-9.

17. Yadav AV, Upasani CD. Nephroprotective activity of Plumeria rubra against cisplatin induced nephrotoxicity in experimental rats. Int $\mathrm{J}$ Pharm Pharm Sci 2019;11108-13.

18. Sura J, Dwivedi S, Dubey R. Pharmacological, phytochemical, and traditional uses of Plumeria alba Linn. an Indian medicinal plant. J Pharm Biosci 2016;1:14-7.

19. Radha R, Sivakumar T, Arokiyaraj S. Pharmacognostical evaluation of Plumeria alba Linn. Res J Pharm Technol 2008;1:496-501.

20. Sumeet D, Abhishek D, Dwivedi SN. Folk lore uses of some plants by the tribes of Madhya Pradesh with special reference to their conservation. Ethnobot Leaflets 2008;12:741-3. 